\title{
PROGRAM SPECIFICATION OF MUSICAL TRAINING IN THE GRAECO-ROMAN EGYPT
}

\section{DOAA ABDEL-MOTAAL AHMED}

FACULTY OF TOURISM AND HOTELS, MINIA UNIVRSITY

\begin{abstract}
Music plays a vital role in Greek civilization and it considered nutrition for the sole of human. Philosophers considered it a mean to be more civilized. For that; learning playing music was very indispensable in first stage of education; every child should know some musical roles. This kind of education was available for all sexes and social classes. In GraecoRoman Egypt, music continued to play an essential role in daily life activities and religious events as indicating by different sources either literal or monumental. One of these sources is a papyrus which was a contract to teach playing aulos with its different types. This contract is considered to be a vocational academic program specification. This study aims to compare between the modern course specification and the GraecoRoman course specification applying analytical methodology. Results of this study indicate the presence of program aim, intended learning outcomes, teaching methods, teaching tools, assessment methods and other aspect of the academic program. The results also provide other aspects of education in Egypt during Graeco-Roman Period.
\end{abstract}

KeYWORDS: Music, Education, Contract, Graeco-Roman, Egypt.

\section{INTRODUCTION}

Music was a word that was usually appeared in Classical works; theatre pieces, philosophy, history. The conclusion of these all sources that the music is not only means of entertainment but also a tool to be well educated, civilized and a remarkable personality. It is one of the most important sign of the development of civilisation and nations (El-Kilany et al.2011). The Greeks were fond of vocal and instrumental music; they considered it as a kind of science and only philosopher and scientist could catch its secrets. Music played an important role in all aspects of life from small and personal events to great religious public festivals. Also, music was mean for strengthen social relationships between individuals and even between person and society (El-Kilany et al.2011; Perpillou-Thomas 1995). 
Alexandria which was the greatest culture centre in Hellenistic and Roman World was, by consequence, a house of music where many musical events took place. It housed many great composers and musicians such as Glauce of Chios who was famous for her versatility and her beauty. She was mentioned by classical writers as a great composer of music using wind instruments (Pliny, Natural History 10, 51). Theocritus indicates that she played a very professional aulet that made the muses, themselves, intoxicated (Idyll 4.31). Plutarch (Sur les oracles de la Pythie, 6, 396 F397 A) and Aelian denote that she was citharist and her sound was a model of musicality (Histoire variée IX, 39). Alexandria was also the residence of many festivals as Ptoleamea when the musician from all cities of Hellenistic World attended to prove their competencies. The citizens of Alexandria were known for their musical passions. The musical events either religious or secular were numerous in other parts of as indicating terracotta, quotations of classical writers, and other documented sources. So, it is normal that teaching music was so common in Alexandria and other parties of Egypt despite the scarcity of archaeological remains that didn't give enough information about it.

Learning music was a pillar in Greek education (Bélis 1999), it was obligatory in some cities as Athens that the children from six year start to learn playing music, especially chordophone instruments. Learning music continued to be vital in Hellenistic World, and some classes of musician were so remarkable in society. So Nobles and Aristocrats in Greek, Hellenistic and Roman Worlds pay attention that their children learn music but not take it as a profession ((El-Kilany et $a l$.$) ,)$

This study aims to compare between the modern program specification and the Graeco- Roman course specification relating to musical education through displaying of a papyrus which was a contract to teach playing aulos with its different types, analyzing its contents. A descriptive and analytical methodology will be applied to achieve the aims of this study.

\section{MODERN PROGRAM SPECIFICATION}

Program specification is a very important approach in education in our modern time. It is considered to be a contract between the academic institution and their students. This contract displays the most important knowledge and skills the student needs to have to compete in the work field. Commonly the program specification includes aims, intended learning outcomes (ILOS), teaching methods, assessment methods, assessment tools, cost, duration and place of the Educational program. It is worthy to mention that all practical fields of education such as music, applied arts depend on practical exams more than written exams. 


\section{THE PAPYRUS (P. BEROL. 13057)}

This papyrus dates back to year 13 B.C. and it was originally conserved in Bureau of Archive of Alexandria; but then, as it became outdated, with other papyri, it was transferred to be used in mummy bandings. It was discovered in the beginning of $\mathrm{XX}^{\text {th }}$ century by German mission directed by Borchardt in Abou-Sir el Malaq, the ancient Busiris, in Beni-Seuf governorate. It was transformed to Berlin and published in Berliner Griechische Urkunden (Schubart 1912, n. 1125). This papyrus was disappeared during the Second World War. It is about 0,12 m large and $0,29 \mathrm{~m}$ high. When it was discovered some parts are missing as the left part and upper part of right side which was cut during the wrapping of the mummy.

This papyrus is of homology and juridical type which starts with "I declare that", the phrase which is cited by the father or the mother of the children or the patron in the case of slave as this papyrus. This type is quite known as a juridical type but it is the only example that concern with education. The first part of the contract is Gaios Ioulios Philos who entrust his slave Nacrisse who almost has 12-15 years old, to a musical teacher named Gaios Ioulios Eros to train him playing different types of aulos. The contract includes a guide of what should be run during the whole scholar year; the aim, what should be learned, teaching material, free days and vacations, assessment methods and exam committee.

THE PROGRAM SPECIFICATION

\begin{tabular}{|l|l|}
\hline Pogram duration & $\begin{array}{l}\text { One year starting from month Pharmuthi }{ }^{1} \text { in the 17 } \\
\text { year of reign of August, 13 B.C. }\end{array}$ \\
\hline Program aim & $\begin{array}{l}\text { Upgrade the competencies of auletes to play different } \\
\text { kind of auloi instruments }\end{array}$ \\
\hline Learning & $\begin{array}{l}\text { Playing seven kinds of aulos as: } \\
\text { outcomes }\end{array}$ \\
\hline
\end{tabular}

${ }^{1}$ Pharmuthi or Barmoudah is the eight month of the Egyptian and Coptic year. It lies between March and April, cf. Clagett, M., (1995), Ancient Egyptian Science, Vol. II, Calendars, Clocks, and Astronomy, Philadelphia. 


\begin{tabular}{|c|c|}
\hline & $\begin{array}{l}\text { 2. Play Syristeridian Aulos } \\
\text { 3. Play different kinds of Citheristerien auloi of } \\
\text { Serapis } \\
\text { 4. Play Carian Aulos ou Pan flute } \\
\text { 5. Paly Egyptian Auloi } \\
\text { 6. Play Phrygian Aulos } \\
\text { 7. Play Auloi like tibia }\end{array}$ \\
\hline $\begin{array}{l}\text { Teaching } \\
\text { materials }\end{array}$ & $\begin{array}{l}7 \text { auloi cited supra and the patron is responsible to } \\
\text { provide it. }\end{array}$ \\
\hline $\begin{array}{l}\text { Assessment } \\
\text { methods }\end{array}$ & $\begin{array}{l}\text { - Practical exam at the clause of the academic } \\
\text { training } \\
\text { - The exam will run before an exam committee } \\
\text { consisting of three experts of music. } \\
\text { - The master is not one of the committee. }\end{array}$ \\
\hline Free days & 17 days + days of feasts \\
\hline Other conditions & $\begin{array}{l}\text { - The master should have a salary payable semi- } \\
\text { annually. The salary is about } 100 \text { silver drachma } \\
\text { of Ptolemy. } \\
\text { - The patron is responsible to provide the trainee } \\
\text { with nutrition and clothes. } \\
\text { - In case of illness of Patron or the trainee, the } \\
\text { prolongation of the duration is obligatory to } \\
\text { cover the days of training. } \\
\text { - It is forbidden that the patron take back his slave } \\
\text { before the expiry of the contract and the } \\
\text { duration of training program is } a d h o c\end{array}$ \\
\hline
\end{tabular}




\section{DISCUSSION AND RESULTS}

The importance of this contract is that it fills up a lacuna in the education process in ancient times. It is well known that the private education was dominant in the Graeco-Roman Egypt and it was the responsibilities of the family or the patron to choose the type of education (Fahim and Zoair 2016). It is was little known how the private education run in this period and what are the juridical obligation of the two axes of education input: teachers and families. In the light of this contract it is quite clear that in some cases and to ensure that every part keep its rights, they sign a contract indicating every detail of education process: duration, objectives, teaching material and outcomes.

In the Graeco-Roman Egypt, the musicians were categorized into two classes: musicians of the synodos and musician of the symphoniai. The First category is considered to be reserved for the Elite of the society and they dealt with respect and appreciations. A group of them is known Technite which included different kinds of professional artists, poets, actors, trumpet players and other types of musicians, especially the citharist (cithara player) and cithardos (who play cithara and sing in the same time). The most important Technite of Dionysus in the Hellenistic World were that of Athens, of Isamus and Nemea, of Ionia and Hellespont and finally of Egypt and Cyprus (Bussirères 2010). The contract seems to refer to teaching one of synodos or Technite. It is evidently that the trainer Gaios Ioulios Eros is a competent musician that was one of the Technite and it seems that he is the responsible to training and acquiring his competencies to slave Narcisse.

The names of two parts of the contract refers probably to two Alexandrian citizen despite the two first names refers to Roman ones, But based on third name which are Greeks. This indicates the importance of music in this city.

The duration of the program for one year, from March $13 \mathrm{BC}$ to March 12 BC., gives an idea about the capabilities of Narcisse. In somehow (not indicated in the contract), he is not a beginner but he attained a level of musical training and he could play certain kinds of aulos. It is difficult to conclude that one year is enough to train someone playing seven different kinds of aulos with different techniques. Certainly, Narcisse had a certain talent in playing aulos, his patron aimed to upgrade his competencies by joining him with a musical teacher to teach him how to play seven kinds of aulos. So, this contract refers to an advanced training program not an initial one. 
The training program has some objectives to be achieved. These objectives are to acquire the skills and abilities to play the known seven types of aulos. Each musical instrument has its melody and the trainee supposed to acquire the knowledge and skills related to every instruments. In a piece that supposed to be related to the contract (P. Berol. 13049) ${ }^{2}$, the patron precise with each instruments the technique by adding the number of instrumental holes, the master should teach him the melody with this number. Also he added some techniques that are difficult to interpret (Bélis and Delattre 1993). These indications will be present before the exam committee to judge the skills of the trainee.These skills qualified Narcisse to play seven instruments of auloi in different events either religious or secular. The religious types are mainly the auloi of Serapis and the Caria aulos. Other type was commonly attested in daily life events as the auloi of Magadis which was so popular in Athenian banquets and usually accompanied by another type of chordophone instruments with the same name (Bélis and Delattre 1993). Other type which was usually attested in banquets festivities is the Carian aulos which was originally used in the funerary context, accompanying the lamentation especially during the ekphora and prosthesis as depicted in some Roman sarcophagus found in Egypt (Fig. 2) and stela (Abdelwahed 2016). The other type as the Syristeridian Aulos is not common in Egypt nor in Greece and it is difficult to precise its context of usage (Bélis and Delattre 1993).

The slave was also prepared to participate in some events that reserved for the member of synodos as the musical competitions inside or outside Egypt. The musical competitions in Greco-Roman Egypt were mainly divided into two types: the competition of periodos and competitions outside of the periodos ((El-Kilany et al 2011). The first kind was supposed to be held every four years in some religious festivals similar to that of some Greek cities (Goukowsky, 1992). The main competition of periodos in the Ptolemaic Period is the Ptolemaea, held every four years in honor of Soter's cult and it resembled the Olympic Games (Goukowsky, 1992). Another musical competition in Alexandria was Olympiokos agon (P. Coll. XIII 7) which was held since the third century B.C. In the Chora, a papyrus dating back to the third century A.D., mentioned the name of some musicians as the kitharist Marcos Aurelios Agathakles, citizen of Alexandria, Antinoopolis and Lecko polis who won the competition of Capitolia and Pythia and some of competitions that aren't of periodos (P. Oxy. XXVII 2467).

\footnotetext{
${ }^{2}$ Schubart give this papyrus the name Entwurf, it is a summary of the original contract and in some parts it give some details which is missing in the original copy
} 
The teaching material was a vital issue in education system of the GraecoRoman Egypt. Its diversity gives a clear idea about the importance to learn. In the vocational training the teaching material was correspond perfectly to the type of training program as carding of woolen, textile, pottery and the stone masonry. All these vocational trainings run in the workshops and teaching material are available in work-place training. But in our case, the location is not mentioned but it could be the house of the master as some words in the contract indicate that the slave is away from his patron. For that, it was indispensable to determine the one who will provide the teaching material, the patron in this contract.

In the end of training program, Narcisse should pass an exam to ensure that the attained the required skills. The exam will be practical and before an exam committee consisting of three musical experts. The patron is the one who choose this committee and if the slave failed to prove his competencies, the patron had the rights to sue the master.

The practical exam was in somehow the dominant method in the GraecoRoman Egypt either in literal or vocational education. What was essential in this environment is to know how doing. The student passes a practical exam to prove his ability to write the Greek alphabet in a right direction. He passed an exam to indicate that he could pronounce correctly the letters and syllabus, and that he could read correctly some quotation of Classical works. In vocational education, practical exam was the only assessment methods as indicating in this papyrus and other similar papyri. Trainee should prove his competencies to control his instruments in a right way.

\section{CONCLUSION}

Comparing between this program specification and modern program specification, shows great similarities between them specially on the main items that commonly included in program specification. The contract includes a guide of what should be run during the whole scholar year; the aim, what should be learned, teaching material, free days and vacations, assessment methods and exam committee. Moreover; concentrating on practical assessment to obtain the various skills of playing music is very similar to modern musical program

The citizens of Alexandria were known for their musical passions. The musical events either religious or secular were numerous in other parts of as indicating terracotta, quotations of classical writers, and other documented sources. So, it is normal that teaching music was so common in Alexandria and other parties of Egypt 
This papyrus indicates that musical education during the Graeco- Roman period is an added value to the student as it prepares them well to the work field. Additionally, it helped them to gain a promising career in their future.

This papyrus is not only a juridical contract between two parts but its date with its location and its topic provide some value information about vocational and musical education in both Hellenistic and Roman Egypt in Alexandria. With other educational papyri, it furnishes some information regarding teaching and assessment methods. It gives insights about very popular instruments, auloi, with its different kinds and playing technique.

\section{BIBLIOGRAPHY}

- Bélis 1999= A. Belis A., Les musiciens dans l'antiquité, Paris, 1999

- Bélis and Delattre 1993= Bélis A. And Daniel Delattre D., "À propos d'un contrat d'apprentissage d'aulète (Alexandrie, an 17 d'Auguste : 13a)." in Papiri Documeentari Greci., Papyrologica, Lupiensia. vol. 2 103-162.

- Bussirères 2010= Bussirères D., Les Associations de Technite Dionysiaque et l'organisation des concours à l'époque hellénistique, Québec, 2010/

- Fahim and Zoair 2016= Fahim T. and Zoair N., "Education in Ancient Egypt till the end of the Graeco-Roman Period: some evidences for quality", Journal of Association of Arab Universities of Tourism and Hospitality, vol.13, p. 1:16.

- EL Kady. "Aulos and Crotals in Graeco-Roman Egypt", Journal og the General Union of Arab Archaeologists, vol 3. p. 70-106.

- El-Kilany, Zoair and Youssef, 2017 "Sound of Music in Egypt, The Musicians of Ancient, Greco- Roman and Byzantine Egypt, a comparative study", Egyptian Journal for tourism and Hospitality, vol.11, p.1:17.

- Goukowsky, 1992= Goukowsky, "Fêtes et fastes des Lagides" in Ch. Jacob and F. Polignac (dir.), Alexandrie IIIe siècle av. J.-C. tous les savoirs du monde ou le rêve d'universalité des Ptolémées, Paris, 1992, p. $152-159$

- Mannich, 1991, "Music and musicians in Ancient Egypt", London.

- Perpillou-Thomas 1995= F. Perpillou-Thomsd, "Artistes et Athlètes dans les papyrus grecs d'Egypte" ZPE 108, 199, p. 225-251. 


\section{FIGURE}

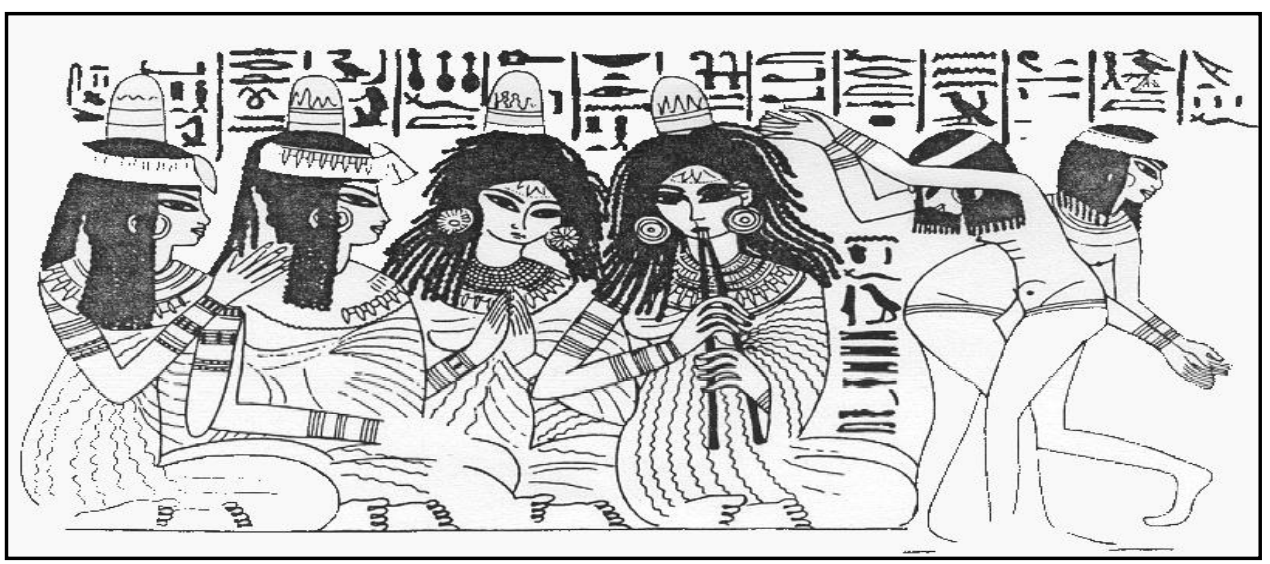

Fig. 1: Pair of female dancers performing with female musicians playing Egyptiqn aulos (tomb of Nebamun, 18th Dynasty, Thebes, after Mannich, Lise, Music and musicians in Ancient Egypt. London, 1991

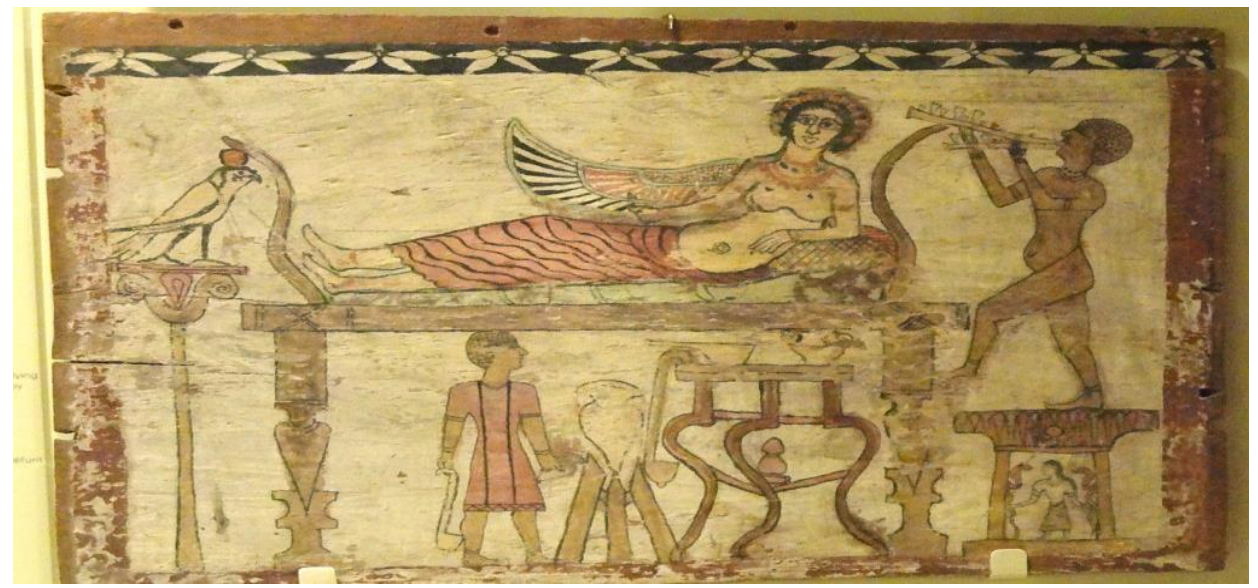

Fig. 2 : Egyptian sarcophagus with a Carian aulos after EL kady M. Aulos and Crotals in Graeco-Roman Egypt", Journal og the General Union of Arab Archaeologists, vol 3., p. 70-106 